\begin{tabular}{|c|}
\hline 報 \\
ORIGINAL PAPER \\
NO. 32
\end{tabular}

\section{ガラス用自動記録膨脹計について}

\author{
岸井貫 \\ （東京芝浦電気粎式会社）
}

\title{
On the Automatic Recording Dilatometer for Measuring the Thermal Expansion of Glass
}

\author{
By Tōru KISHII
}

(Lamp and Tube Manufacturing Department, Tokyo Shibaura Electric Company)

The construction and the operation of the automatic recording dilatometer which was developed for measuring the thermal expansion of glas is described. The sample, $10 \mathrm{~cm}$ long and $1.5 \sim 2.0 \mathrm{~mm}$ in diameter, was heated at a constant rate, and the temperature was recorded by an automatic temperature recorder. The expansion of the sample was magnified by an optical lever having the effective length of about $5 \mathrm{~mm}$, and was traced by a tracer mechanism. This mechanism drived therecording chart of the recorder, and as the result, the expansion curve of the sample was drawn on the chart.

Several improvements were also made on the dilatometer to increase its accuracy.

Results of the measurements for three kinds of glass are described briefly.

\section{緒咅}

管球用ガラスの常温から転移点を経て屈伏点にいた る熱膨脹曲線は，金属索た他種のガラスとの封着に 関係する外，品質管理にも必要なデータとしてしばし

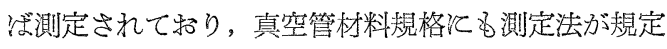
されている．本報でね，ガラス工場に沶いて，品質管 理のために日常行われている測定を自動化し，ガラス の膨脹曲線を自記させる目的で製作した膨脹諳につい て報告する。

\section{I. 構 成 (Fig. 1 参照)}

この膨脹計ほ真空管材料規格による石英ガラス製示 差膨脹計 ${ }^{122}$ を自記化したものである。試料ガラスと 石英ガラスとの膨脹差を光学テコを用いて光点の移動 量江変換，拡大した。 一定速度で上昇する試料温度を 記録温度計に指示させる一方，光点の移動を光電導セ ルを利用した追跡子に追跡させ，追跡子の移動飞連動 して記録温度計の記録紙を送るようにした・との結 果，記録紙上には温度を横軸とし，試料と石英ガラス との膨脹差を縦軸とした膨脤曲線が画かれることとな った.

Fig.1 亿和いて，電気炉F以直径 $10 \mathrm{~cm}$. 長さ 20

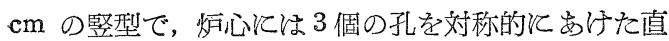
径 $2.8 \mathrm{~cm}$, 長さ $17 \mathrm{~cm}$ の黄銅心を入れて, 試料部分 の温度を均一にした。 また炉外被内面, 黄銅心の上下 面等は石綿板でよく熱絶縁して，局部的冷却による温 度分布の不均一をさらに小さくした。

黄銅心の孔汸いすれ石英ガラス管を入れ，それ ぞれに標準となる石英ガラス棒,アルメルークロメル熱

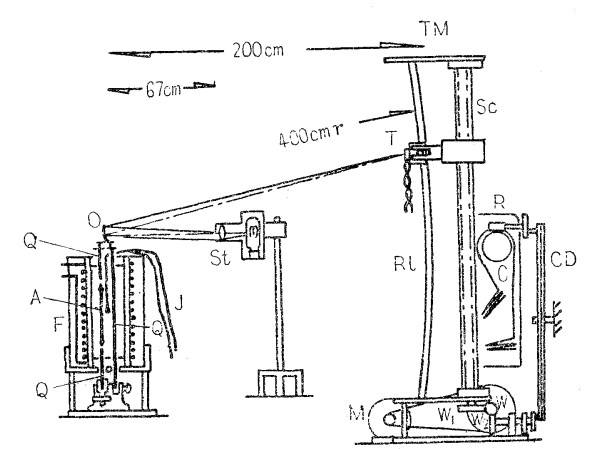

A: Sample Q: Silica glass rods $F$ : Furnace O: Optical lever with a concave mirror.

J : Thermo-junction. St: Semi-circular slit.

T: Tracer. Sc: Screw bolt for driving tracer.

TM: Tracermechanism. Rl: Rail for the tracer. $M$ : Motor for driving the tracer mechanism.

$\mathrm{W}_{1}, \mathrm{~W}_{2}$ : Worm wheels. W: Worm.

C : Recording chart.

CD : Chart driving mechanism by means of a pantagraph. R : Recorder

Fig.1 Schematic representation of the automatic recording dilatometer.

電対ならび試料ととれを上下から支える 2 本の石英 ガラス棒を挿入した。試料㥀径 $1.5 \sim 2.0 \mathrm{~mm}$ ，長 さ $10 \mathrm{~cm}$ とした。 また，以上の電気炉部分は同型の ものを2 個備え，交互に使用して測定回数を増した。

試料と石英ガラスとの膨脹差は，標準石英ガラス棒 と試料上方を支える石英ガラス棒との関係位置の変化 そなるので，この雨方にまたがる光学テコによって拡 大した. 光学テコの有効脚間距離ほ比較的長く約 5 $\mathrm{mm}$ であって, 焦点距離 $50 \mathrm{~cm}$ の四面鏡を備えた。

光学テコ $\mathrm{O}$ の前方 $67 \mathrm{~cm}$ の所に光源のスリット $\mathrm{St}$ を置くと，その実像が光学テコから $200 \mathrm{~cm}$ 離れた追 
跡子T上に生じるようにした。

試料の温度多横河電機製電子管式自動平衡型温度記 録調節計を用いて記録した。測温範团视 $0^{\circ} \sim 800^{\circ} \mathrm{C}$ で、スケールウは $18 \mathrm{~cm}$ であった。

記録調節計飞付属した調節器を Fig. 2 のよう飞改造 乙て炉温の上景速 度を調整した。指 針I と共江移動す る抵抗 $R_{2}$ の瀷動 端子x と, 抵抗 $R_{3}$ の摺動端子 y との 間飞電位差が生じ ないようと，平衡 電動機 BMが y 駆動するので，y 飞対して固定され たスライダック $\mathrm{S}$ の搖動端子飞移動 し，炉温上昇と共 飞炕游る電圧 が堌加するように なった. $\mathrm{R}_{3}$ の固定 端子 $\mathrm{t}$ 招よび $\mathrm{u} の$ 位置の調整，短絡 子を用いることに よる $R_{2}$ の抵抗分 布の調整，並びそ

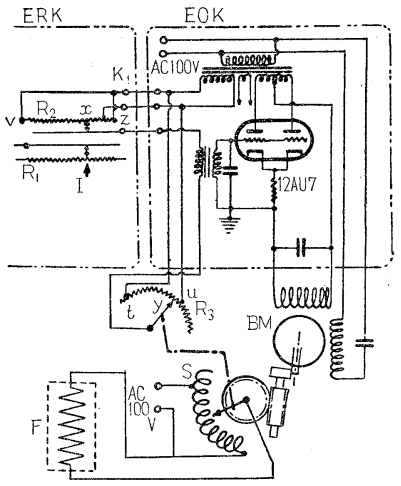

ERK : ERK type recording controllerfor temperature measurement.

EOK: EOK type controller.

$\mathrm{R}_{1}$ : Slide resistor for temperature measurement.

$\mathrm{R}_{2}$ : Slide resistor for temperature control.

$R_{3}$ : Slide resistor for regulating the handle of a slidac.

$\mathrm{BM}$ : Balancing motor.

F : Furnace. S: Slidac.

I : Indicator.

Fig.2 Circuit for regulating heating up rate of the dilatometer furnace.

温度上昇が速い方の炬飞直列抵抗を付加すること飞よ り，二つの炡の温度上昇の仕方をFig.3のようと潘

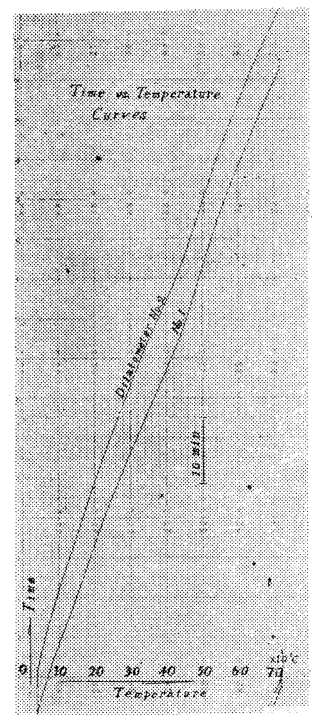

Fig.3 Time vs. temperature curves for dilatometers No.1 and No.2
同一かつ一定にすることが できた。な掠，Fig.2 亿标 いて抵抗 $\mathrm{R}_{2}$ の $\mathrm{z}$ 端子を $\mathrm{v}$ 端子V結んでので，弱温が $700^{\circ} \mathrm{C}$ を超すと電压が下 り，Fig.3 飞見られるよう に焰の過熱が防がれた。

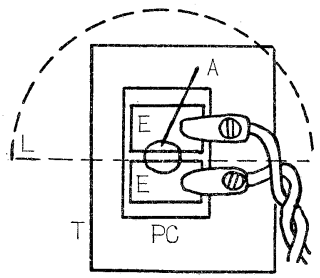

T: Tracer.

PC: Photo-conducting cell.

E: Electrodes.

A : Photo-conducting material.

L : Light spot (Real image of the slit).

Fig.4 Construction of the する必要がある (Fig.6 参照)。この膨脹計では追 tracer. 線が記録紙上に画かれた。

\section{II. 測定法に対する討論}

ガラスの膨脹曲線測定に当り問題となるのは加熱速 度である、特に転移点は加熱速度に影響されると考兄 られる。真空管材料規格には $5^{\circ} \mathrm{C} / \mathrm{min}$ と定められて いるが，䈣密な測定にはこれでも速過ぎるとの意見が しばしば述べられている。しかし工場実験としてね測 定に長時間を費やすことほできず，特に筆者の場合， 一定時間内の測定回数が少いと自動記録膨脹計慜作の 意義が失われる事情があったので，結局 $6 \sim 7^{\circ} \mathrm{C} / \mathrm{min}$ の加熱速度を採用した。しかし炉和よび炉心の䄇造， 材質に注意してあるので，加熱速度が大きいことによ る温度分布の不均一や，試料と熱電対との温度差等の 影響は少いであろろ。

この型の膨脹計では，膨張差 $\Delta 1$ と記録紙の送り，

したがって追跡子の垂直移動距離 $\Delta \mathrm{L}$ とが正比例 跡子を導くレール Rl (Fig.6 㐨よび Fig. 1) の曲率
追跡子（Fig.1 T） 前面の構造ならびそ光点との関 係位置は Fig. 4 の通りで, 光電導セル PC を備えて 招り，試料が膨脹すると光点Lが下方へ動き，セルの

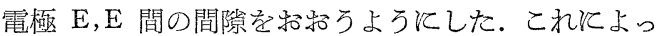
て電極間の電気抵抗が低くなるから，Fig. 5 亿示した 回路のサイラトロンのグリッド電位が上昇することと なる。したがってサイラトロンが発火し，リレー Ry と水銀りレー My を経てモーター M (Fig. 5 和よび Fig. 1) が回転する。回路の調整ほ容易であった。

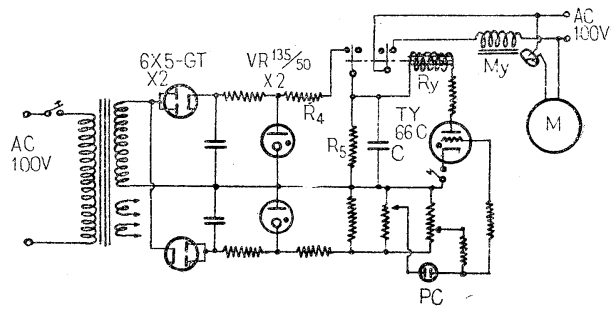

$M$ : Motor for driving the tracer mechanism. Ry: Relay.

My: Mercury relay.

PC : Photo-conducting celi.

Fig.5 Amplifier circuit with a photo-conducting cell.

Fig. 1 K和いてモーター M はウォーム W，ウォ一 ム車 $W_{I}$ を経て追跡子駆動用ネジボルト Sc を备軾 させ，追跡子 $T$ を下方飞移動させるから，追跡子は (Fig. 4 参照) 光像 L の下端と, セルの下方電極の上 端とが常に接するような位置を保ら，光像と共に移動 することとふった・ウォームW (Fig. 1 参照) ほまた ウォーム車 $\mathrm{W}_{2}$ ，パンタグラフを経て記録計 $\mathrm{R} の$ 記録 紙Cを送るので，前に述べた理由により試料の膨脹曲 
半径を $400 \mathrm{~cm}$ とし たが，この場合は曲 率半径を $200 \mathrm{~cm}$ ま たは無限大としたい ずれの場合よりも正 比例関係がよく成立 乙, 比膨脹差 $\Delta 1 / 1$ が零に近い時の光学 テコの拡大率 $2 \mathrm{H} / \mathrm{h}$ と, $\Delta 1 / 1=50 \mu / \mathrm{cm}$ のとき拡大率 $\Delta \mathrm{L} / \Delta 1$ との差到 $0.25 \%$ に 過ぎない。

光電尊セルの電極 間隙は $1 \mathrm{~mm}$ 過ぎ ないし，なもし光 点の下縁とセル下方 電極の上縁とが互V 平行な直線をなして いるならば，セルは $1 \mathrm{~mm}$ よりはるか、

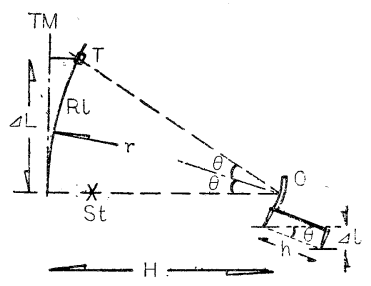

11: Differential expansion

$\triangle \mathrm{L}$ : Translation of the tracer mechanism.

$\mathrm{H}$ : Distance between the optical lever and the rail on which the tracer moves.

h: Effective length of the optical lever.

$\theta:$ Inclination of the optical lever.

O: Optical lever

$T$ : Tracer.

TM: Tracer mechanism.

R1: Rail on which the tracer moves.

St: Slit of the light source.

$r$ : Radius of curvature of the rail.

Fig.6 Schematic explanation of the magnification factor of the optical lever and the tracer mechanism.
小さい光点の移動を検出して追跡子を移動させるはず である. 光点のピントのボケがあれば，この検出しろ る最小移動量がとれだけ大きくなってしまうけれぞ も, 四面鏡の直径が $1 \mathrm{~cm}$ 以下なので，焦点合わせが 適切であれば，レールの曲率半径等の影響によるボケ ほ $0.1 \mathrm{~mm}$ 超えないと計算され，無視できる。

モーターM (Fig.1 特よび Fig. 5) の慣性により 追跡子が行過ざることは 誤差の原因となるが，

Fig. 5 に揭げた回路によ りこれを小さくすること ができた。すなわちサイ ラトロンは， $\mathrm{R}_{4}, \mathrm{R}_{5}, \mathrm{C}$ 掠 よびリレー Ryの機械的 常数等によって定まる時 間間隔を福いて短時間ず つ発火するので，モ一夕 ーM微動を繰返しなが ら追跡子を送り, 追跡子 の行過ざは十分小さくな った.この点については 他㳊も, 適当なモーター の選定，ブレーキの採用 等が考えられるである 万.

この膨脹計の拡大率, すなわち比膨脹差 $\Delta 1 / 1$
とそれに対応する記録紙の送りとの比は，光学テコの 有效脚間距離 $\mathrm{h}$, 光学テコと追跡子のレールとの距離 $\mathrm{H}$, 追跡子送りネジボルト (Fig. $1 \mathrm{Sc}$ ) のピッチ, 記 録紙送り機構の寸度等から計算することができるけれ

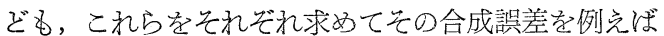
1\% 以下にするのは困難と考光られた。この膨脹計で は，膨脹係数既知の試料を測定した結果から拡大率を 算出した。乙試料が適当ななましを受けていて，加

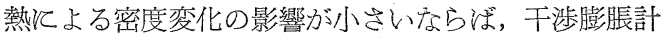
によって例光ば $100^{\circ} \sim 300^{\circ} \mathrm{C}$ 間の平均膨脹係数を土 0.5\%の再現性で測定でき3，この值ね加熱速度によ

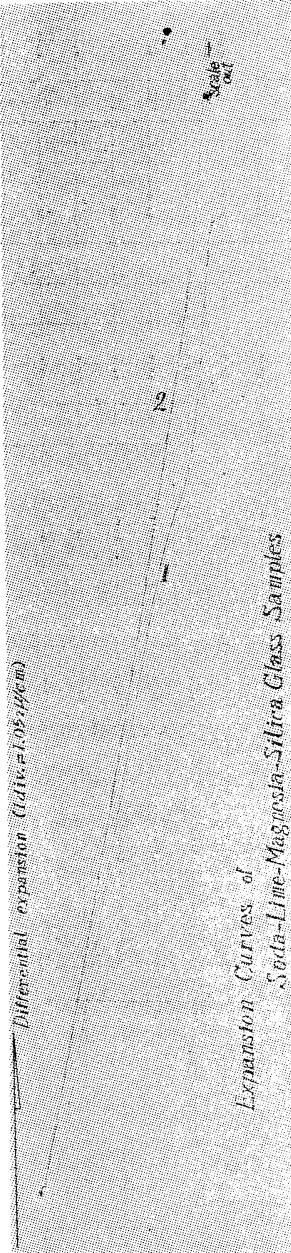

Teuperiture L whe

1) Chilled sample.

2) Annealed by heating up to the contraction temperature.

3) Annealed by heating up the annealing point.

Fig.7 Expansion curves of Terex glass* samples. (* A sodaborosilicate glass, Pyrex chemical resistant type)

1) Chilled sample.

2) Annealed by heating up to the contraction temperature. ing tubes. to the neighbourhood of って変らないと考光らる から，同じ試料をこの膨脹 計で測った結果から拡大率 が計算される。乞の結果を Fig. 7 ないし Fig.9 の縦

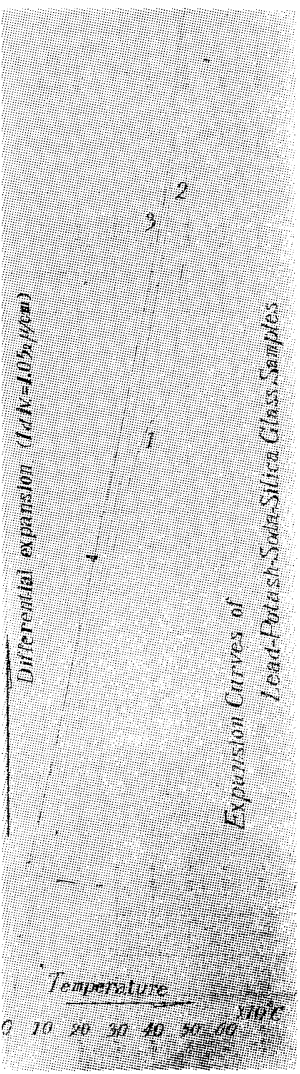

(1) 10 20 39 40 50 o0 70 1) Chilled sample.

Fig.8 Expansion curves of a soda-limemagnesia-silica glass used for the bulbs of lamps and receiv-
2) Annealed by heating up to the contraction temperature. 3) Annealed by heating up to the neighbourhood of the annealing point.

Fig.9 Expansion curves of a lead-potashsoda-silica glass used for the stems of receiving tubes. 
軸飞記入した. 䏓の加熱の仕方は常に同じであるか ら, 仮飞試料部分の温度不均一があったとしても, 以 上の方法で拡大率を求めれげその影響は一応打消され てしまうであろう。

\section{III. 測 定 結 果}

テレックスガラス (Pyrex chemical resistant 型 ソーダ硼珪酸ガラス), 電球和よび受信管バルブ用ソ ーダー石灰一マグネシャーシリカガラス，ならびに受信 管ステム用鉛一カリーソーダーシリカガラスについての 測定結果を Fig. 7 ないし Fig. 9 亿揭げた。 バルブ ガラスとステムガラスは低温では膨脹曲線が下に凸で あること，急冷されたままのガラス祢 $250^{\circ} \sim 300^{\circ} \mathrm{C}$ 以 上飞保たれると密度增加，乙たがって収縮を起し，曲

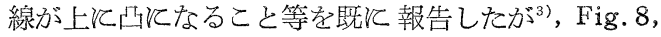
Fig. 9 亿る同じことが珰められる。テレックスガラス の膨脹係数がなましにより低下すること，常温から $300^{\circ} \mathrm{C}$ までほ曲線深渒線と見なし得るが， $300^{\circ} \mathrm{C}$ 付近で上に凸になる傾向を示すことも前報告の通りで ある。

一般に急冷されたガラスは再加熱により，構造の緊 密化飞よる密度増加, したがって収縮を起すため, 転 移点付近で膨脹係数が見掛上低下することはこれらの

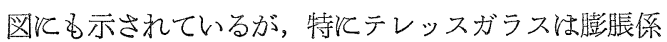
数が小さいために，収縮の方が熱膨脹より大きくなる 温度範囲 (Fig. 7 急泠試料曲線 1 の $460^{\circ} \sim 590^{\circ} \mathrm{C}$ ) が めり,ここでは膨脹曲線は点線で定性的に示したよう そなるのであるが，この膨脹計は試料の収縮ふ追跡し ないので，この範囲は直線で結ばれている。しかしこ の膨脹計は真空管材料規格にしたがい，ないした試料 の膨脹曲線を得ることを目的としているので，このよ うなとと塳支えない。

これらの曲線から求めた膨脹係数は, 従来使用され て来た膨脹計とよる值と満足な程度に一致した。

\section{総 括と結 言}

真空管材料規格によるガラス用膨脹計を自記化した 装置飞ついて報告した。試料を一定速度で加熱してそ
の温度を記録計に指示させる一方, 試料の膨脹を光学 テコにより光点の移動に変換, 拡大して追跡し, 追跡 子飞連動して記録紙を送って行く方法で，記録紙上飞 ガラスの膨镺曲線を自動的に画くことができた．装置 の各部にも改良を加完てあるため，自記化した沉るか かわらず満足な精度が得られた。

この膨脹計は, 電気的ふたは機械的に無理江拡大率 を大きくすることを避け，有效脚間距離が長い光学テ コにより純光学的に拡大しているので, 問題が少い,

この膨脹計ほガラス工場に沶いて日常行われている 膨脹測定を能率よく行う目的で製作されたので，この ための単能機として機構学簡単にし，取扱いをできる だけ容易にしてある。研究用としては加熱, 冷却速度 の変化や定温保持もでき，末た試料の収縮も追跡する ようなものが必要であろうが，このようにするための 原理的困離主全然なく，この膨脹計飞利用された機構 を用いて十分製作可能であるが，製作目的から，従来 の髇脹計の測定者飞熟練を要しないで报えるように， あ党て機構の複雑化を避けたものである。ガラスと金

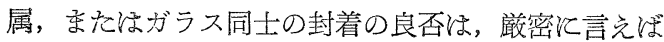
封着温度から常温まで温度を下げて行った時の和の稆 のの膨脹监線から判定すべきるのであるが，実際には 真空管材料規格による測定加ら，低い温度範囲以和け る膨脹係数と転移点とを求めれば，十分良否を予測で きるので，この膨脹計のようと簡単化したものでも利 用範目は広いのである。

本膨脤計飞用いた記録調節計の製作とは，横河電機 製作所挍術部の方々の御配慮を受け，また，膨脹計の 製作汇当りマツダ研究所安部俊夫博士をはじめ東京芝 浦電気株式会社の方々の御指導, 御協力を得たことを 付記して，謝意を表する。

\section{文献}

1） T. Abe，マツダ研究時報, 5, p.167 (1930)

2) 真空管材料規格, VMS 31 (7-4) 第 2 条

3) T. Kishii, Proc. 4th International Congress on Glass P. 244 (1956)

$(5 / 19 / 57$ 受付 $)$

文 献 目 録

\section{1. 原料}

\section{オレゴン・ワシントン・モンタナ・アイダホ洲にお} ける㯺業の発達とその原料資源 H.J. Kelly, K.G. Strandberg and J.I. Mueller, U.S. Bur. Mines Inform Circ., No. 7752,77 pp. (56)
害業用陶土一その起源・性質・用途 R.A. Green, Pottery Gaz., 81 [954] 1732-35 (56)

独国ゲッチンゲン付近の三畳紀赤色層中に含まれる 粘土鉱物 F. Lippmann, J. Sediment Petrol., 26 [2] 125-39 (56)

フランスにおける白雲岩（ドロマイト）の主用途と 鉱床 V. Charrin, Génie civil, 133 134-36 (56)

ほたる石と氷晶石 J.E. Holtzinger and L.C. Roberts, U.S. Bur. Mines Minerals Yearbook (rep- 